\title{
ハイダクティリティー鋼製橋脚の 耐震性能に関する実験的研究
}

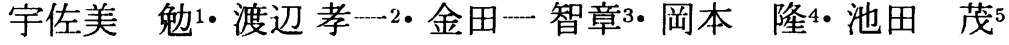 \\ 1フェロー会員 D.Sc. 工博 名古屋大学教授 大学院工学研究科土木工学尃攻 (广 464-8603 名古屋市千種区不老町) \\ ${ }^{2}$ 正会員 工修 横河ブリッジ株式会社 （テ 108 東京都港区芝浦 四丁目 4 番 44 号） \\ 3 学生会員 名古屋大学大学院 工学研究科土木工学尃攻 (前期課程) ( \\ ${ }^{4}$ 正会員 工博 （社）日本橋梁建設協会 (下 104 東京都中央区銀座二丁'目 2 番 18 号) \\ ${ }^{5}$ 正会員 （社）日本橋梁貄設協会（空104 東京都中央区銀座二丁目 2 番 18号）
}

\begin{abstract}
補剛箱形断面鋼製橋脚の耐震性能を支配する主要力学的パラメータ汸フランジ幅厚比パラメータ $R_{f}$, 細長比 パラメータ $\bar{\lambda}$, 補剛材剛比 $\gamma$, 補剛材細長比パラメータ $\bar{\lambda}_{S} か ゙$ 挙げられる. 過去の実験成果を踏まえ, 高い変形性 能 (ハイダクティリティー) を発揮する鋼製橋脚の設計法が文献 1 ) で提案されている. 具体的に恃幅厚比および 補剛材細長比をある值以下に制限し, 補剛材剛度を高めるこ上によって構成補剛板の局部座屈の発生を遅らせ, ダクティリティーの大きな橋脚を設計しようとするものである．上記の考えで設計製作した鋼製橋脚モデルを 兵庫県南部地震の観測地震波を用いたハイブリッド地震応答実験を行い, 鋼製橋脚の耐震性能の確認を行った.
\end{abstract}

Key Words : steel bridge pier, ductility, pseudodynamic test, seismic design.

\section{1. 緒言}

兵庫県南部地震による被害を踏まえ, 鋼製橋脚の耐 震性向上の有力な手段として, 鋼製橋脚基部にコンク リートを部分的に充填する方法が著者らによって提案 され2), 具体的な設計法の提示もなされている1). また, 平成 8 年 12 月に改訂された道路橋示方書・ $\mathrm{V}$ 耐震設計 編4にも設計法が新たに設けられている.

一方、文献1)では, コンクリートを部分充填するこ となく鋼部材のみで箱形断面あるい怯パイブ断面銅製 橋脚の変形性能（ダクティリティー）を向上させる設 計法が提案されている.すなわち, 単柱式補剛箱形断 面橋脚の場合には, フランジ補剛板の幅厚比および補 剛材の細長比交る值以下に制限し, かつ補剛材剛度 をある值以上にすることにより，目標塑性率（地震荷 重が与えられたときに構造物が安全であるために要求 される性能一要求性能一) に応じて橋脚の細長比を制 限する設計法である.この設計法の, 具体的な内容に ついては次節で述べるが，これを適用することにより， 設計者が目標とする変形性能を有する鋼製橋脚を設計 寸ることが可能であり、変形性能の高い鋼製橋脚（ハイ ダクティリティー鋼製橋脚）を設計することが可能と なる. 寸なわち、この論文では, ハイダクティリティー 橋脚とは, 要求性能としての目標塑性率を上回るよう な変形性能を有する橋脚という意味で用いている.

本研究は, この方法で設計された, 目標塑性率（最
大水平荷重に対応する水平変位を降伏変位で除した量) が 6.0 程度の鋼製橋脚（補剛箱形断面）供試体に, 兵庫 県南部地震で観測された 3 種類の地震動およびそれを 増幅した地震動を用いてハイブリッド地震応答実験を 行い, その耐震性能を実験的に確認し, 提案橋脚の八 イダクティリティー性を実証する.

\section{2. ハイダクティリティー鋼製橋脚の設計思 想1}

鋼製橋脚の強度と変形能は, 種々のパラメータの影 響を受ける. 単柱式の補剛箱形断面鋼製橋脚に対して, ハイダクティリティーを得るための設計条件が下記の ように提案されている1). 寸なわち, 現行の道路橋示方 書4)に基づく 1 次設計時に, フランジの幅厚比パラメー 夕 $R_{f}$, 細長比パラメータ $\bar{\lambda}$, 縦方向補剛材剛比 $\gamma / \gamma^{*}(こ$ こに、 $\gamma^{*}$ は最適剛比) および縌方向補剛材の細長比パラ メータ ${ }^{3} \bar{\lambda}_{s}$ に以下のような制限を加える.

$$
\begin{gathered}
R_{f}=\frac{b}{t} \sqrt{\frac{\sigma_{y}}{E} \cdot \frac{12\left(1-\mu^{2}\right)}{\pi^{2} k}} \leq 0.35 \\
\bar{\lambda}=\frac{2 h}{r} \cdot \frac{1}{\pi} \sqrt{\frac{\sigma_{y}}{E}} \leq 0.35 \\
\gamma / \gamma^{*} \geq 3.0 \\
\bar{\lambda}_{s}=\frac{1}{\sqrt{Q}} \frac{a}{r_{s}} \frac{1}{\pi} \sqrt{\frac{\sigma_{y s}}{E}} \leq 0.2
\end{gathered}
$$


Table 1 Measured Dimensions

\begin{tabular}{|c|c|c|c|c|c|c|c|c|c|}
\hline No. & Specimen & $\begin{array}{c}l_{d} \\
(\mathrm{~mm})\end{array}$ & $\alpha$ & $\gamma / \gamma^{*}$ & $\bar{\lambda}_{s}$ & $\bar{\lambda}$ & $R_{f}$ & $\begin{array}{r}H_{y} \\
(\mathrm{kN})\end{array}$ & $\begin{array}{r}\delta_{y} \\
(\mathrm{~mm})\end{array}$ \\
\hline 1 & S2-35-35-M[05] & 164 & 0.5 & 3.36 & 0.196 & 0.362 & 0.353 & 100 & 7.08 \\
\hline 2 & S2-35-35-T[05] & 164 & 0.5 & 3.39 & $\overline{0.196}$ & $\overline{0.362}$ & 0.355 & 100 & 7.07 \\
\hline \multirow{2}{*}{3} & S2-35-35-H[05](JMA) & \multirow{2}{*}{164} & \multirow{2}{*}{0.5} & \multirow{2}{*}{3.40} & \multirow{2}{*}{0.196} & \multirow{2}{*}{0.362} & \multirow{2}{*}{0.355} & 100 & 7.07 \\
\hline & S2-35-35-H[05](JRT)-2 & & & & & & & 103 & 7.54 \\
\hline \multirow{2}{*}{4} & S2-35-35-H[05](JMA)L & \multirow{2}{*}{164} & \multirow{2}{*}{0.5} & \multirow{2}{*}{3.37} & \multirow{2}{*}{0.196} & \multirow{2}{*}{0.362} & \multirow{2}{*}{0.354} & 100 & 7.07 \\
\hline & S2-35-35-H[05](HKB)L-2 & & & & & & & 106 & 7.52 \\
\hline \multirow{2}{*}{5} & S2-35-35-H[05](HKB) & \multirow{2}{*}{164} & \multirow{2}{*}{0.5} & \multirow{2}{*}{3.37} & \multirow{2}{*}{0.196} & \multirow{2}{*}{0.363} & \multirow{2}{*}{0.354} & 105 & 7.47 \\
\hline & S2-35-35-H[05](JRT)L-2 & & & & & & & 103 & 7.12 \\
\hline \multirow{4}{*}{$6^{+}$} & $\overline{\mathrm{S} 2-35-35-\mathrm{H}[10](\mathrm{JMA})}$ & \multirow{4}{*}{328} & \multirow{4}{*}{1.0} & \multirow{4}{*}{0.79} & \multirow{4}{*}{0.391} & \multirow{4}{*}{0.362} & \multirow{4}{*}{0.353} & 104 & $\overline{7.08}$ \\
\hline & S2-35-35-H[10](JRT)-2 & & & & & & & 103 & 7.41 \\
\hline & S2-35-35-H[10](JMA)L-3 & & & & & & & 101 & 7.65 \\
\hline & S2-35-35-H[10](JRT)L-4 & & & & & & & 103 & 7.91 \\
\hline \multirow{4}{*}{7} & S2-35-3.5-H-HS[05](JMA) & \multirow{4}{*}{164} & \multirow{4}{*}{0.5} & \multirow{4}{*}{3.35} & \multirow{4}{*}{0.203} & \multirow{4}{*}{0.374} & \multirow{4}{*}{0.366} & 107 & $\overline{7.58}$ \\
\hline & S2-35-35-H-HS[05](JRT)-2 & & & & & & & 110 & 7.92 \\
\hline & S2-35-35-H-HS[05](JMA)L-3 & & & & & & & 107 & 7.77 \\
\hline & S2-35-35-H-HS[05](JRT)L-4 & & & & & & & 110 & 8.34 \\
\hline Note & $\begin{array}{l}L=1554(\mathrm{~mm}), h=1388(\mathrm{n} \\
t=t_{s}=6.1(\mathrm{~mm}), b_{s}=34.0 \\
+=\text { Not designed in accor }\end{array}$ & $\begin{array}{l}B= \\
\mathrm{m}),\end{array}$ & & & $\overline{211}$ & & & & \\
\hline
\end{tabular}

ただし，

$$
\begin{gathered}
Q=\frac{1}{2 R_{f}}\left[\beta-\sqrt{\beta^{2}-4 R_{f}}\right] \leq 1.0 \\
\beta=1.33 R_{f}+0.868
\end{gathered}
$$

ここで, $b=$ フランジ幅, $t=$ フランジ板厚, $\sigma_{y}=$ 板 ハネルの降伏応力, $\sigma_{y s}$ = 補剛材の降伏応力, $E=$ 弾 性係数, $\mu$ =ボアソン比, $k=4 n^{2}$ = 板の座屈係数, $n$ =補剛材で囲まれたサブバネル数, $h=$ 柱長, $r=$ 断 面 2 次半径である.

式(2)の条件は, 式(1),(3),(4)の条件のもとで, 目標 塑性率(塑性率は, 最高荷重の水平変位を降伏水平変位 で除した量で定義する)を 6.0 程度とするために設けら れた制限である1)。

な㧍, 補剛材細長比パラメータ $\bar{\lambda}_{s}$ は, フランジ補剛 板のアスペクト比 $\alpha=l_{d} / b$ (Fig.1参照) が 0.5 以下で式 (1), (3)の条件を満たすときは, 式 (4)の条件, すなわ ち $\bar{\lambda}_{s} \leq 0.2$ を満たす ${ }^{3)}$.

このような制限を設けて設計した補剛箱形断面鋼製 橋脚では, 橋脚基部の局部座屈の発生・進展が遅らさ れ, またP- $\Delta$ 効果が抑制されるため, 高い変形能を発 揮寸る1).

さらに，同一設計条件の基で縦補岡材の鋼種を板パ ネルより高強度のものにし、補剛材の降伏を遅らせた, いわゆるハイブリッド補剛箱形断面鋼製橋脚はさらに 耐震性能が向上する3),5).

\section{3. 実験概要}

\section{（1）实㰸供試体}

同一寸法の片持柱鋼製橋脚モデルを 7 体製作した. 供 試体の概念図をFig.1，実測寸法を Table 1に示寸，た だし、Noteに記載の寸法は全供試体の平均值を示す. 製 作には板厚. $6 \mathrm{~mm}$ のSS400 材を用いた. No.6の供試体は ダイヤフラム間隔が他の供試体の倍であり, No.7の供 試体は縋方向補剛材にSM570材を用いたハイブリッド 補剛断面供試体である. Table 2 に製作に使用した鋼 板から切り出した JIS $1 \mathrm{~A}$ 号試験片による引張試験結果 を示寸。

Table 1 に示した供試体名は, 供試体が持つ力学的 パラメータと, その供試体に対して行った実験の種類, 


\begin{tabular}{|c|c|c|c|c|c|c|c|c|}
\hline No. & Specimen & G.T. & $\frac{P}{P_{y}}$ & $\begin{array}{c}T \\
(s e c)\end{array}$ & $\begin{array}{c}E_{6 e} \\
(k N \cdot \mathrm{cm})\end{array}$ & $\frac{\delta_{R}}{\delta_{y}}$ & $\frac{\delta_{\max }}{\delta_{y}}$ & $\sum_{E_{e}} E$ \\
\hline \multirow{2}{*}{3} & S2-35-35-H[05](JMA) & $\mathrm{I}$ & 0.176 & 0.962 & 35.3 & -1.14 & -3.84 & 33.4 \\
\hline & S2-35-35-H[05](JRT)L-2 & II & 0.153 & 0.914 & 38.8 & 3.11 & 9.02 & 90.4 \\
\hline \multirow{2}{*}{4} & S2-35-35-H[05](JMA)L & I & 0.176 & 0.962 & 35.5 & -0.65 & 4.43 & 80.0 \\
\hline & S2-35-35-H[05](HKB)L-2 & III & 0.131 & 0.835 & 39.8 & -2.81 & -5.90 & 28.3 \\
\hline \multirow{2}{*}{5} & $\mathrm{~S} 2-35-35-\mathrm{H}[05](\mathrm{HKB})$ & III & 0.131 & 0.833 & 39.4 & -1.27 & -3.16 & 12.9 \\
\hline & S2-35-35-H[05](JRT)L-2 & II & 0.153 & 0.888 & 36.6 & 7.07 & 13.7 & 191.3 \\
\hline \multirow{4}{*}{6} & $\mathrm{~S} 2-35-35-\mathrm{H}[10](\mathrm{JMA})$ & $\mathrm{I}$ & 0.176 & 0.963 & 36.7 & -1.51 & -4.05 & 32.7 \\
\hline & S2-35-35-H[10](JRT)-2 & II & 0.153 & 0.906 & 38.3 & 3.42 & 9.41 & 91.8 \\
\hline & S2-35-35-H[10](JMA)L-3 & $\mathrm{I}$ & 0.176 & 1.000 & 38.4 & -1.20 & -4.45 & 60.3 \\
\hline & S2-35-35-H[10](JRT)L-4 & II & 0.153 & 0.937 & 40.9 & 4.31 & 9.28 & 157.1 \\
\hline \multirow{4}{*}{7} & S2-35-35-H-HS[05](JMA) & $\mathrm{I}$ & 0.176 & 0.994 & 40.4 & -1.22 & -4.12 & 30.5 \\
\hline & S2-35-35-H-HS[05](JRT)-2 & II & 0.153 & 0.937 & 43.4 & 2.45 & 8.63 & 90.7 \\
\hline & S2-35-35-H-HS[05](JMA)L-3 & $\mathrm{I}$ & 0.176 & 1.007 & 41.4 & -1.86 & -5.41 & 60.8 \\
\hline & S2-35-35-H-HS[05](JRT)L-4 & II & 0.153 & 0.961 & 45.7 & 2.84 & 10.6 & 172.5 \\
\hline & Note & \multicolumn{7}{|c|}{ G.T. = Ground Type, $E_{e}=H_{y} \cdot \delta_{y} / 2$} \\
\hline
\end{tabular}

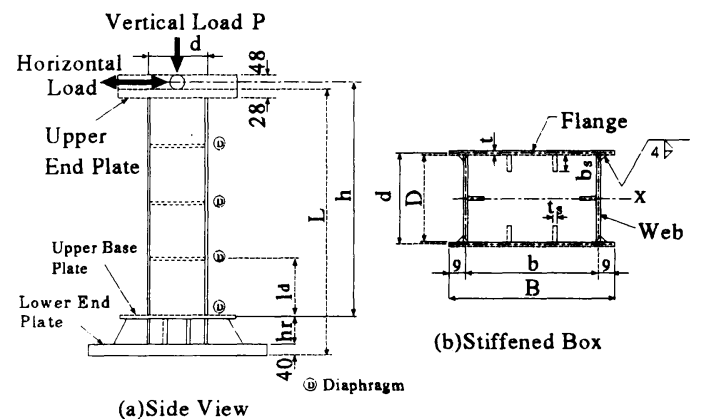

Fig.1 Test Specimen

およびハイブリッド実験においての入力地震波が何で あるかが分かるように付けられている. 初めに付く S2 はフランジに 2 本の補剛材を有する補剛箱形断面鋼製 橋脚を意味し, 次に続く 2 析の数值は順にフランジ幅 厚比パラメータ, 細長比パラメータの設計時の值をそれ ぞれ 100 倍した值を示している. 続く M は単調載荷実 験, T は変動変位振幅の繰り返し載荷実験 (後述の降伏 変位 $\delta_{y}$ ごとに変位を増大させ, 各変位の綝り返し数 $\mathrm{n}$ は 1)，Hはハイブリッド実験を示し， [05]，[10]は供試体の アスベクト比 $\left(\alpha=l_{d} / b\right)$ がそれぞれ $0.5,1.0$ であるこ 之交示寸，-HSは，縦補剛材に高強度の鋼材を使用した 供試体の略称である. 小括弧内の JMA, JRT, HKB と, それに続く L はハイブリッド実験における入力地震波 の略称であり, 詳細は後に示す. 供試体名最後の $-2,-3$, -4 注同一供試体の実験順番を示している.

実験供試体は, フランジ幅厚比パラメータ $R_{f}=0.35$,
細長比パラメータ $\bar{\lambda}=0.35$ に統一されている。これら を設計条件の違いで大別するとアスペクト比 $\alpha=0.5$ で補剛材剛比 $\gamma / \gamma^{*}=3.0$ の No.3, 4 および 5 の供試体, $\alpha=1.0$ で $\gamma / \gamma^{*}=0.7$ のo. 6 供試体, さらに $\alpha=0.5$, $\gamma / \gamma^{*}=3.0$ でハイブリッド補剛の No.7 供試体の三種に 分けられる. これらの供試体の内, No.6を除く供試体 がハイダクティリティーの設計条件を満足する.

Table 1 には各供試体の降伏水平荷重 $H_{y}$ および降伏 水平変位 $\delta_{y}$ が示されている. 降伏水平荷重は文献 3$) 0$ 方法で求め, 降伏水平変位は $H_{y}$ に対応寸る変位でせん 断変形の影響も考えてある.

\section{（2）入力地震波}

本研究では, 兵庫県南部地震で観測された地震波の内, I 種地盤用として神戸海洋気象台 (以下 JMA)，II 種地盤 用としてJR 鷹取警報地震計 ${ }^{6}$ ) (以下 JR-Takatori また は JRT)，III 種地盤用として東神戸大橋 (以下 HigashiKobe または HKB) の観測地震波を入力してハイブリッ ド奏験を行った.

さらに, 各地震波に対し加速度を線形的に 1.5 倍して 得られる地震波を増幅地震波と定義し, 地震波の名称 の後に-L を付けて表記する.

\section{（3）実釦方法}

Table 3にハイブリッド実験用供試体の入力地震動 および入力順序, 想定地盤種 (G.T.), 軸力比 $P / P_{y}$ およ び想定実橋脚 (相似比 $S=8$ を仮定) の固有周期 $T$ を示す. 固有周期は $\bar{\lambda}$ が一定であるため全供試体でほぼ一定の 0.9 秒前後である. 後述のように, このような橋脚は JRTakatori 地震波に対して非常に大きな忘答を示す．軸 


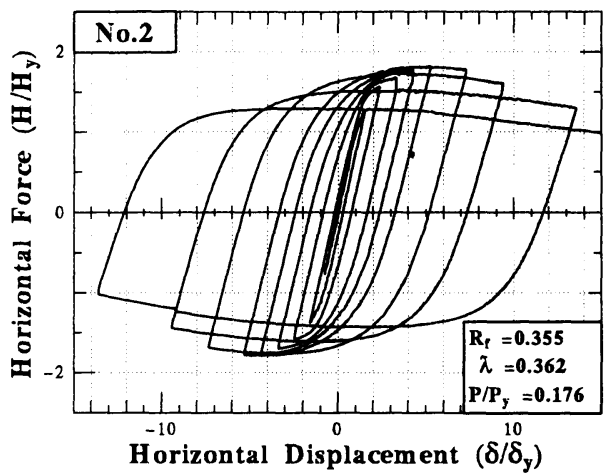

(a) Cyclic Test $(n=1)$

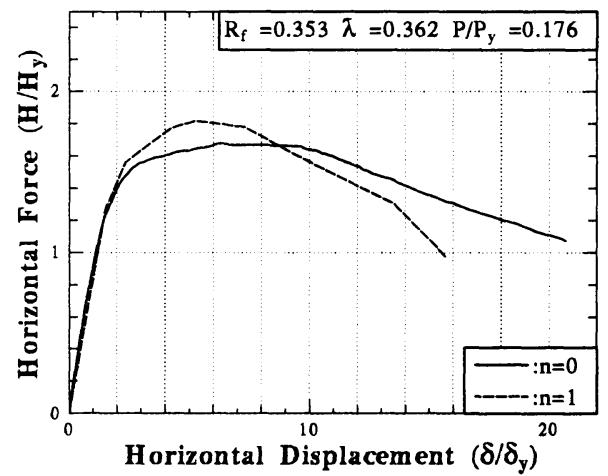

(b) Envelope of Cyclic Test $(n=1)$ and Monotonic Test $(\mathrm{n}=0)$

Fig.2 Cyclic and Monotonic Test Results

力比 $P / P_{y}$ 汇現行道路橋示方書4)の震度法に基づいて求 められた ${ }^{3)} . \delta_{m a x}, \delta_{R}, \sum E$ はそれぞれ実験における 最大応答変位, 残留変位, 履歷吸収エネルギーである. ハイブリッド実験は文献 7)の実験手法の内, 実験手法 2 (相似モデル解析型手法) を用い, 減衰定数は $\xi=0.05$ を用いた。

\section{4. 実験結果および考察}

\section{（1）単調載荷実験およひ準静的实磁結果}

Fig.2(a)にNo.2 供試体に対する準静的実験結果, Fig.2(b)に同結果の包絡線 $(n=1$ と記載) をNo.1 供試 体に対寸る単調載荷実験結果 $(\mathrm{n}=0$ と記載) と比較して 示吉，ここで，Hは水平荷重, $\delta$ は対応寸る水平変位で ある.これらの図から分かるように, No.2 供試体の履 歴曲線は紡鍾形で，エネルギー吸収能力は大きく，から 最高荷重後の強度劣化はなだらかで非常に優れた変形 性能を持つ. 最大荷重時の変位 $\delta_{m}$ で測った塑性率 $\delta_{m} / \delta_{y}$ は概略 6 程度で, 設計時での想定どおりの結果となって いる. 単調載荷実験結果は, $H_{\max } / H_{y} \simeq 1.7$ の強度を 発揮し, 変形が $10 \delta_{y}$ 付近に達寸るまで強度低下はない.
繰り返し載荷実験結果注, 最大荷重が単調載荷実験 に対し $9 \%$ ぼ大きくなっている.これは繰り返しひず み硬化 (Cyclic Strain-hardening) $)^{8}$ の影響であると思わ れる. 繰り返し載荷の影響は最大荷重以後の挙動に現 れ, 繰り返し実験の包絡線は, 最大荷重に達した後の 荷重低下が単調載荷実験に比較して急である.

\section{（2）ハイブリッド地震応答実㰸結果}

Fig.3、Fig.4およびFig.5に 3 種類の供試体にJMA, JR-Takatori およびHigashi-Kobe 地震動を入力した場 合のハイブリッド地震応答実験結果を示す．Fig.3の JMAについて, (a) No.6, (b) No.3, および (c) No.7 の応答に大きな違いは見られず, 最大応答変位と降伏変 位の比 $\delta_{\text {max }} / \delta_{y}$ は 4 程度で, 耐力の低下は見られない. 局部座屈に上る橋脚の損傷は耐力の低下が始まってか ら顕著になることから，JMAによる橋脚の損傷はいず れの供試体でもほとんどなく, アスペクト比 $\alpha=1.0$ の No.6 供試体でも問題は生じない. これは, この橋脚 の固有周期が 0.9 秒前後と比較的大きかったことが原因 である.これについては, 後で再度述べる.

JR-Takatoriは, 最大加速度が 641gal と JMAの最大 加速度 $818 \mathrm{gal}$ より小さいが，Fig.4に見られるように， 供試体に大きな損傷を与える場合がある.アスペクト 比 $\alpha=1.0$ の供試体 No.6 では地震開始後 5.8 秒付近で 最大応答 $\delta_{\max } / \delta_{y}=9.41$ を示すと共に劣化域に入り, 柱基部フランジの局部座屈による損傷が顕著になる. そ の後、橋脚は 1 方向に傾いたまま振動し, そのため残留 変位は $\delta_{R} / \delta_{y}=3.42$ と大きい. これに対し $\alpha=0.5$ の No.3では, 最大応答時での耐力低下はほとんど見られ ず（従って，フランジの局部座屈波形はごくわずかし か見られず), 残留変位は $\delta_{R} / \delta_{y}=3.11$ と No.6 に対 し $10 \%$ 小さく抑えられている.さらにハイブリッド補 剛断面の No.7 では, 最大応答時で耐力低下は全く見ら れず, 残留変位は $\delta_{R} / \delta_{y}=2.45$ となり, No. 5 に対して $30 \%$ 程度小さく抑えることができている. JR-Takatori のような固有周期 1 秒前後の橋脚に大きな応答を生じさ せるような地震動に対して, ハイダクティリティー鋼 製橋脚は優れた耐震性能を発揮すると言える. それれに 対してアスペクト比 $\alpha=1.0$ の No.6 は, 耐力の劣化が 生じており, JR-Takatoriに対しては損傷が大きい橋脚 であると言える.

Photo 1はJR-Takatori を入力した実験の終了後の 供試体を示したもので, (a) がNo.6 供試体 $(\alpha=1.0)$, (b) が No. 3 供試体 $(\alpha=0.5)$ である. 3 重の横線を引い た部分がダイアフラムの位置を示す.

Fig.5の Higashi-Kobeに関しては, JMA と同様に最 大耐力に達しておらず, 残留変位も比較的小さく, 従っ 

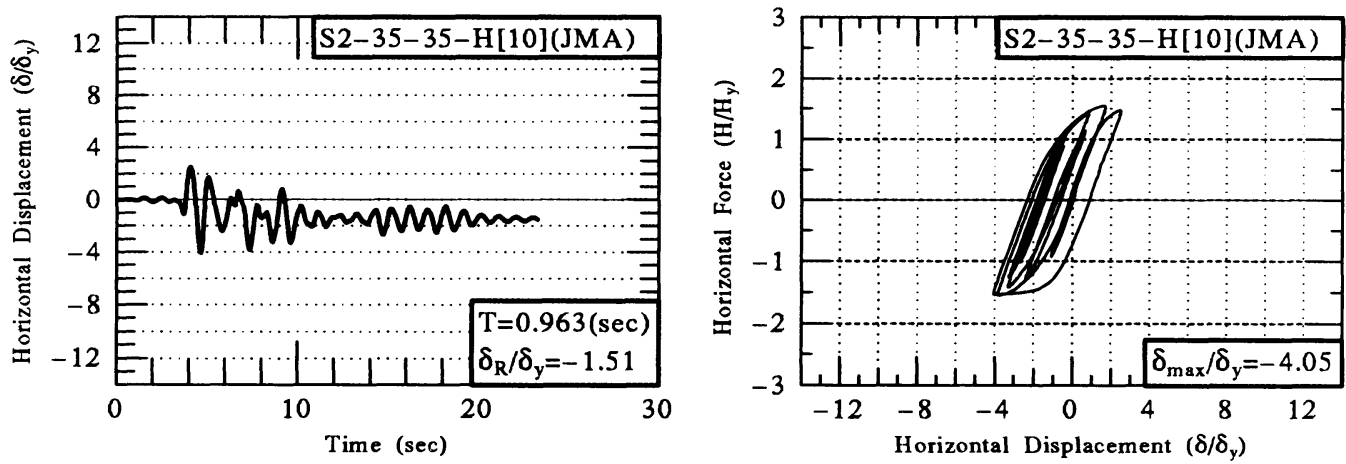

(a) Specimen No.6 $[\alpha=1.0]$
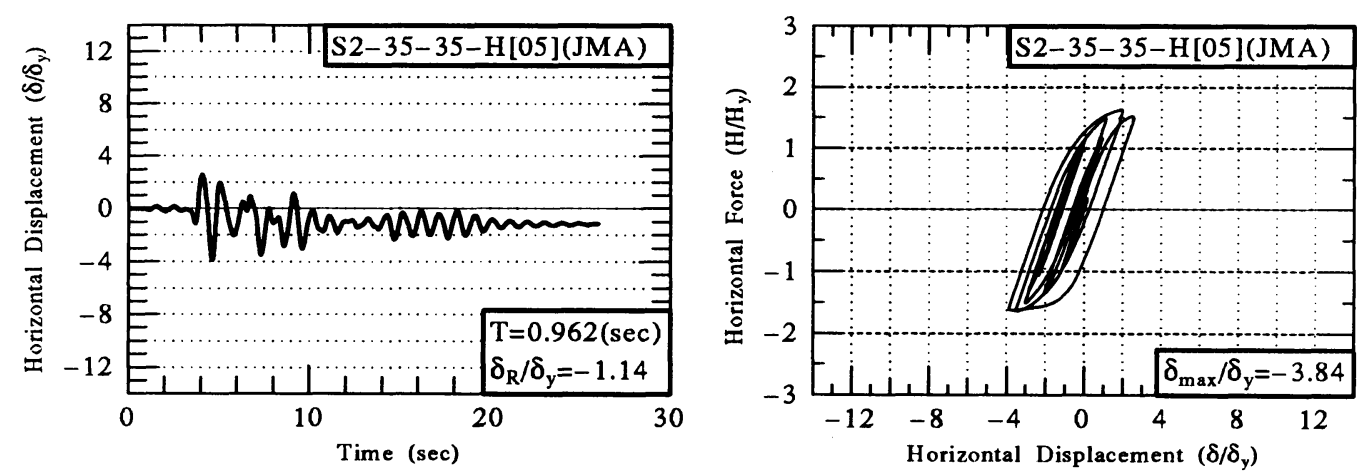

(b) Specimen No.3 $[\alpha=0.5]$
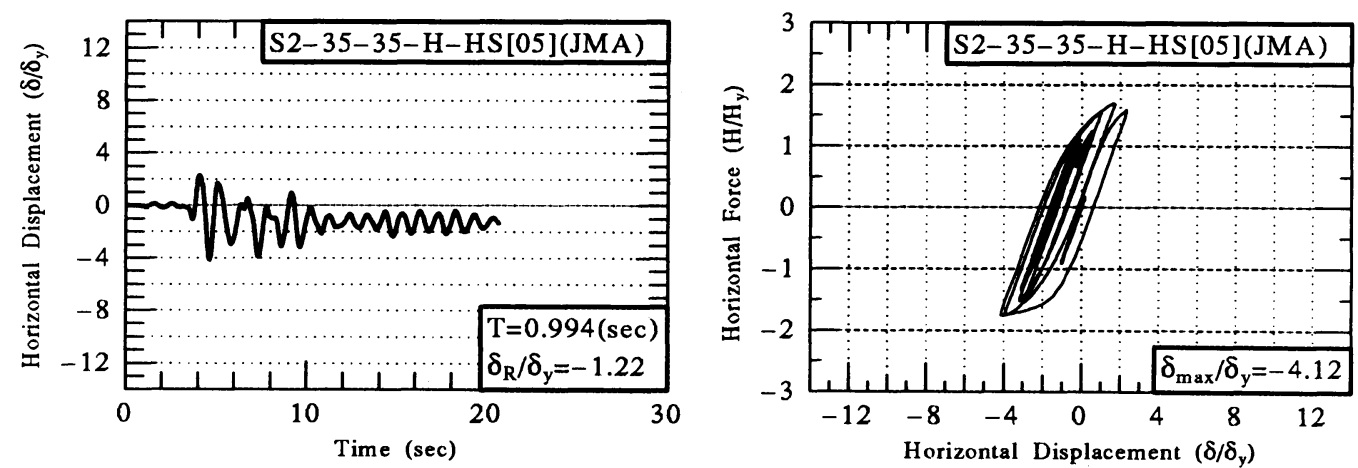

(c) Specimen No.7 [Hybrid]

Fig.3 Responses due to JMA 

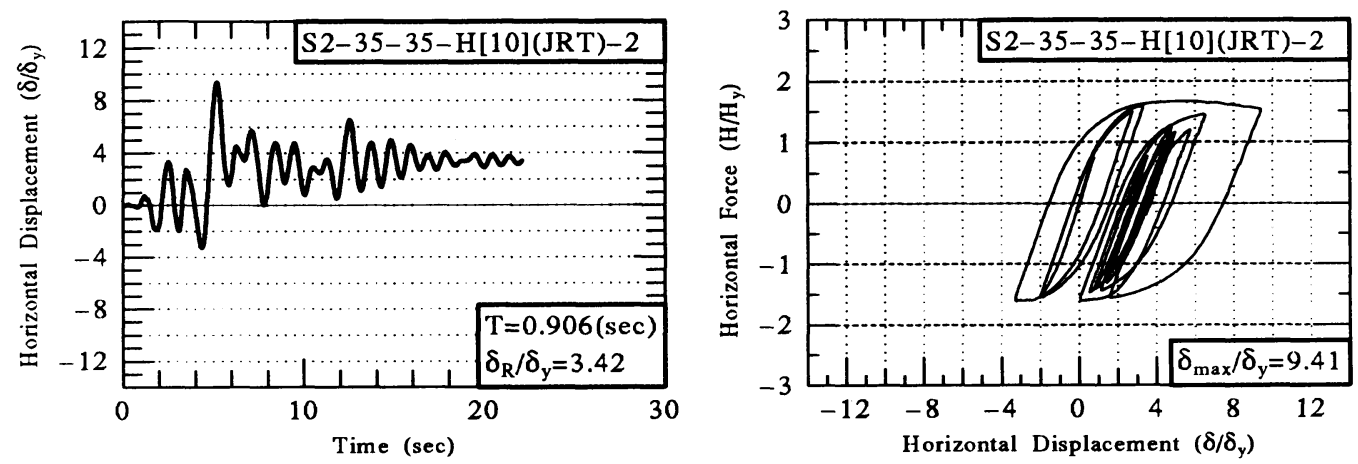

(a) Specimen No.6 $[\alpha=1.0]$
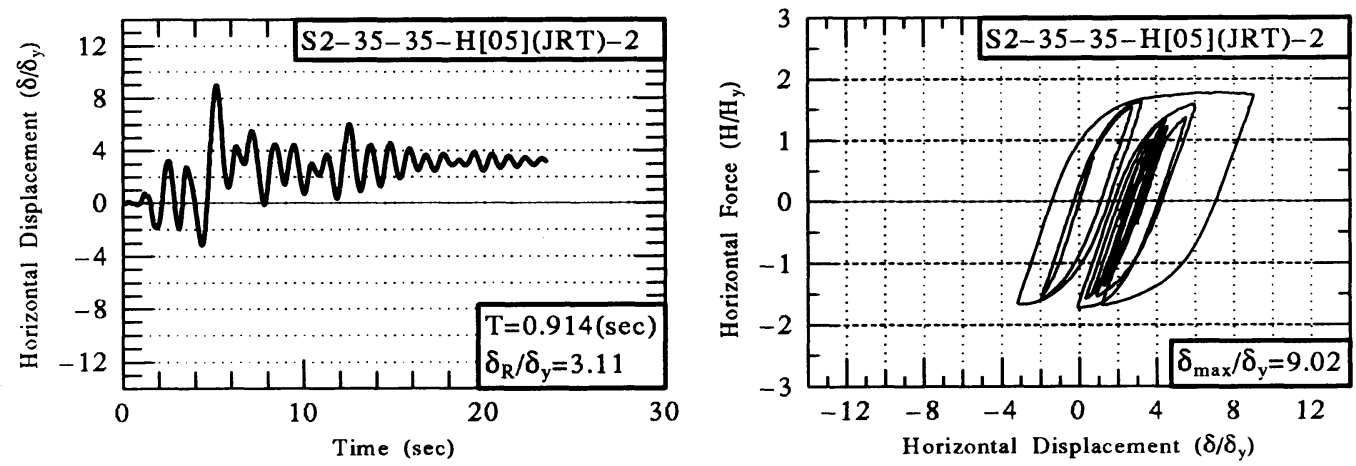

(b) Specimen No.3 $[\alpha=0.5]$
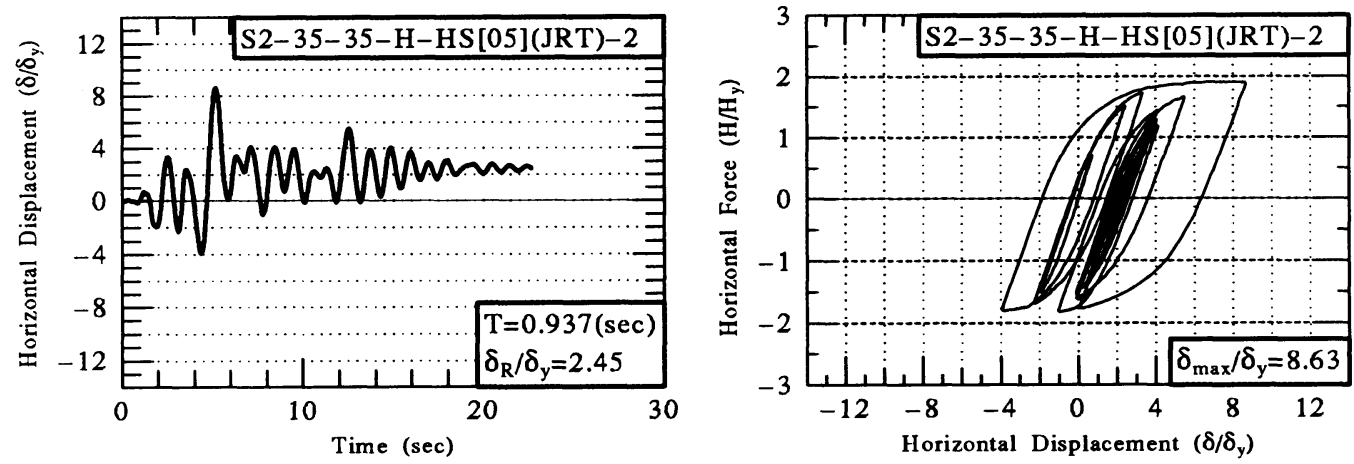

(c) Specimen No.7 [Hybrid]

Fig.4 Responses due to JR-Takatori
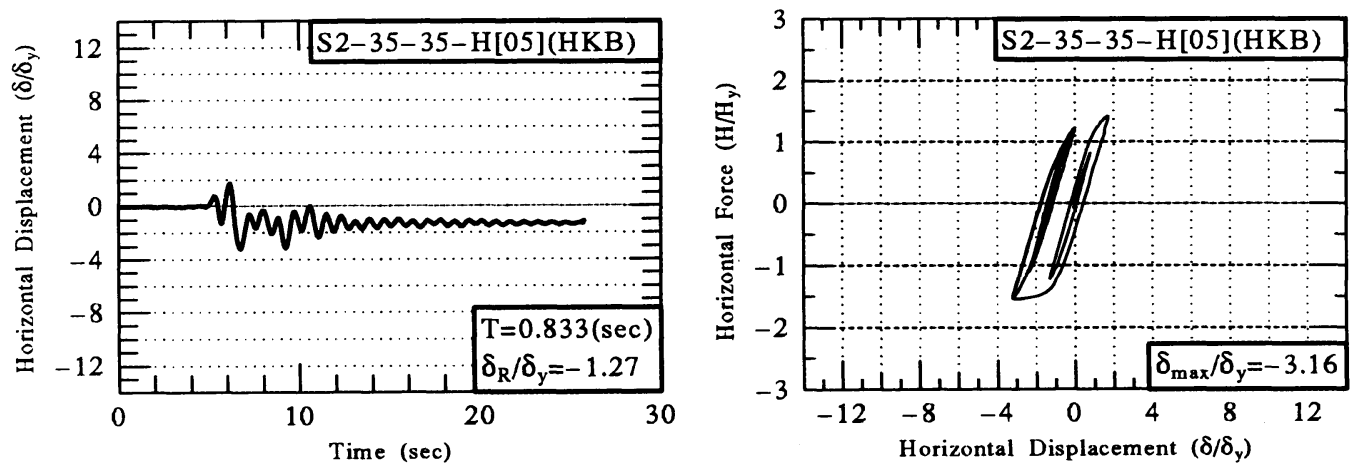

Fig.5 Response due to Higashi-Kobe (Specimen No.5) 

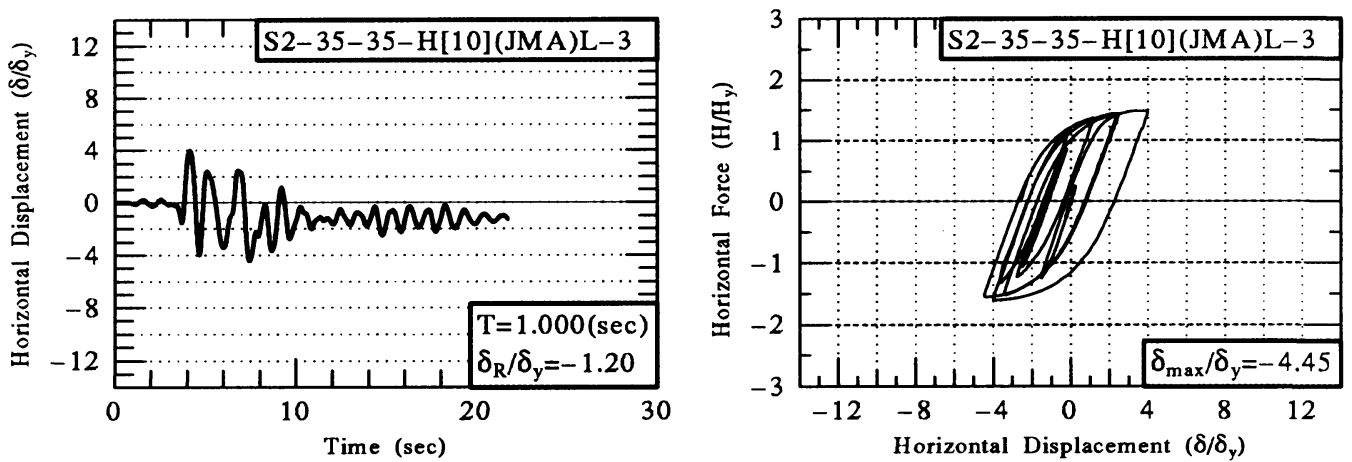

(a) Specimen No.6 $[\alpha=1.0]$
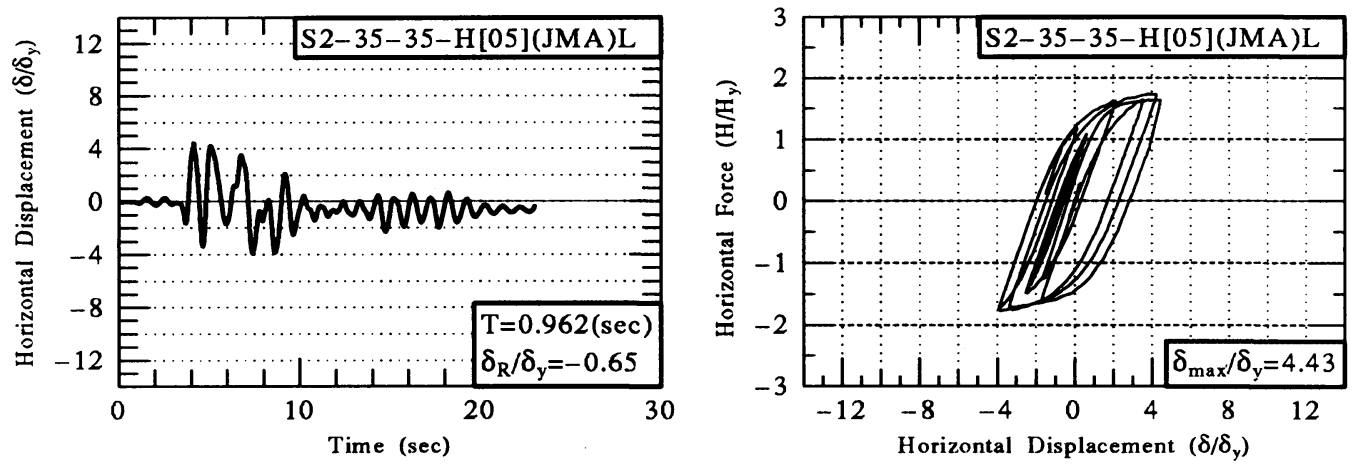

(b) Specimen No.4 $[\alpha=0.5]$
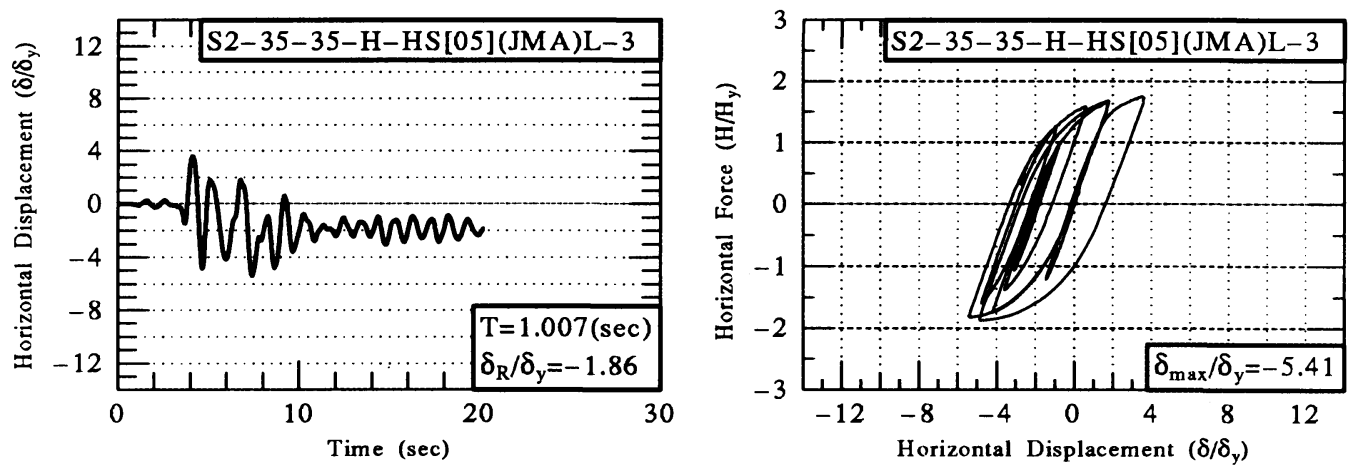

(c) Specimen No.7 [Hybrid]

Fig.6 Responses due to Amplificed JMA 

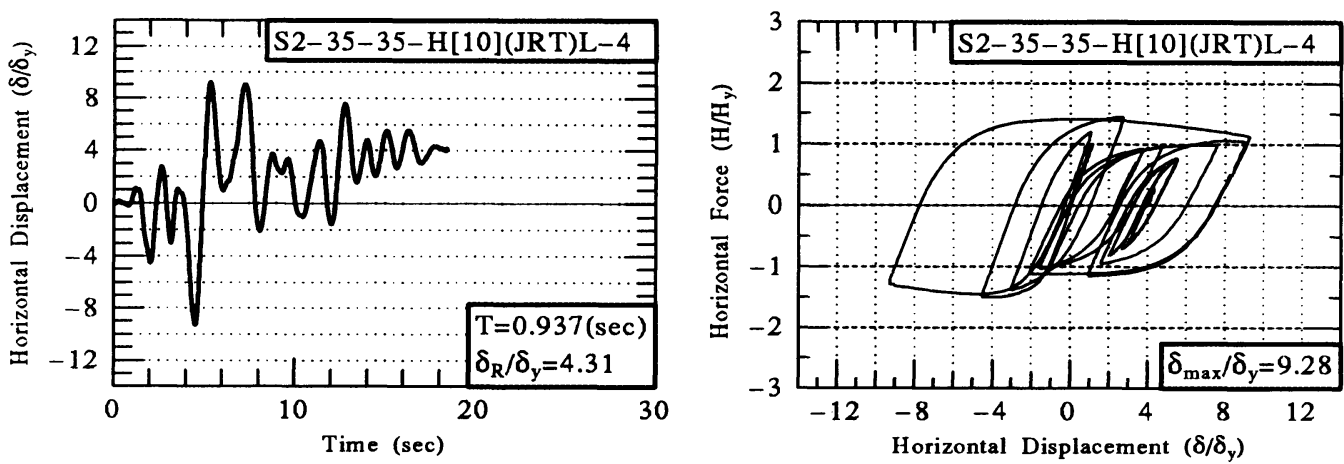

(a) Specimen No.6 $[\alpha=1.0]$
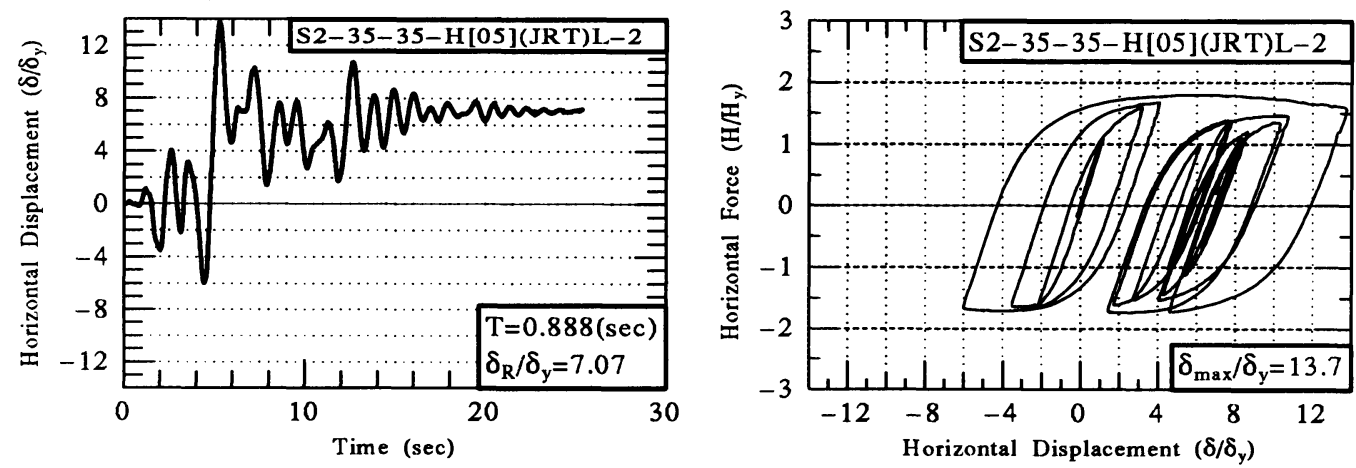

(b) Specimen No.5 $[\alpha=0.5]$
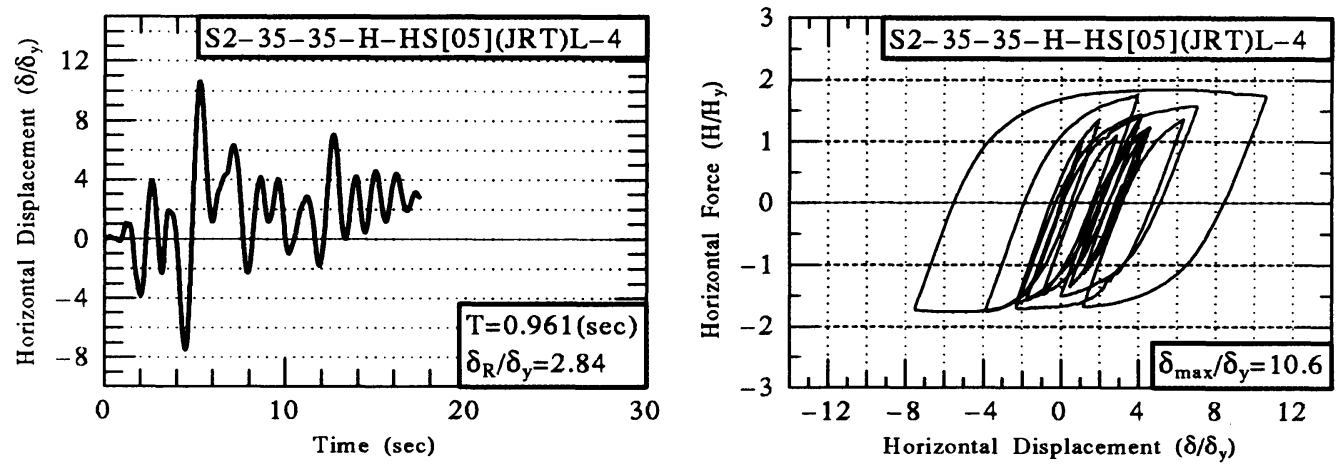

(c) Specimen No.7 [Hybrid]

Fig.7 Responses due to Amplificed JR-Takatori
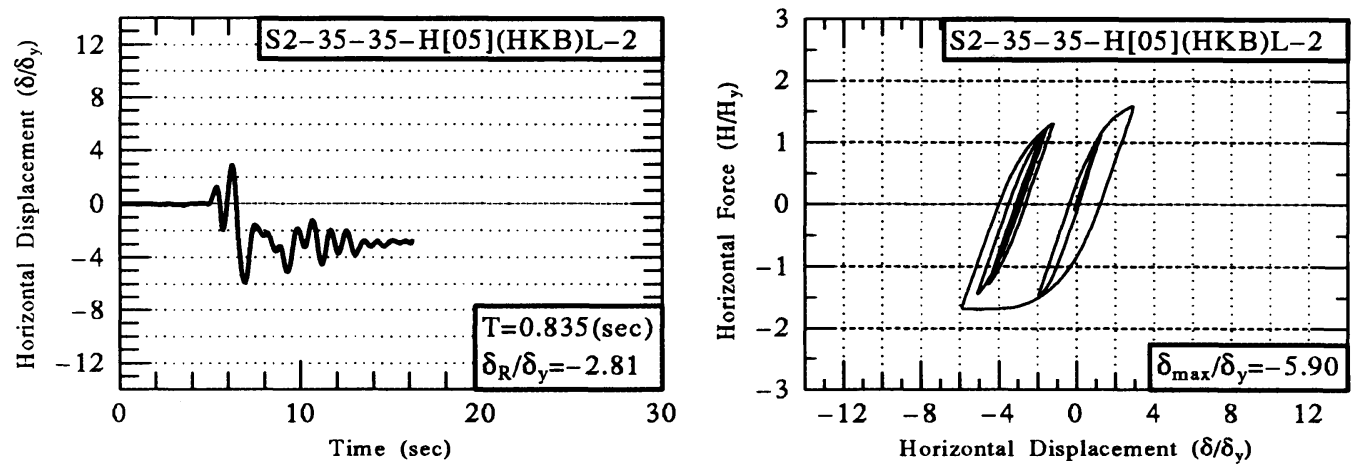

Fig.8 Response due to Amplificed Higashi-Kobe (Specimen No.4) 


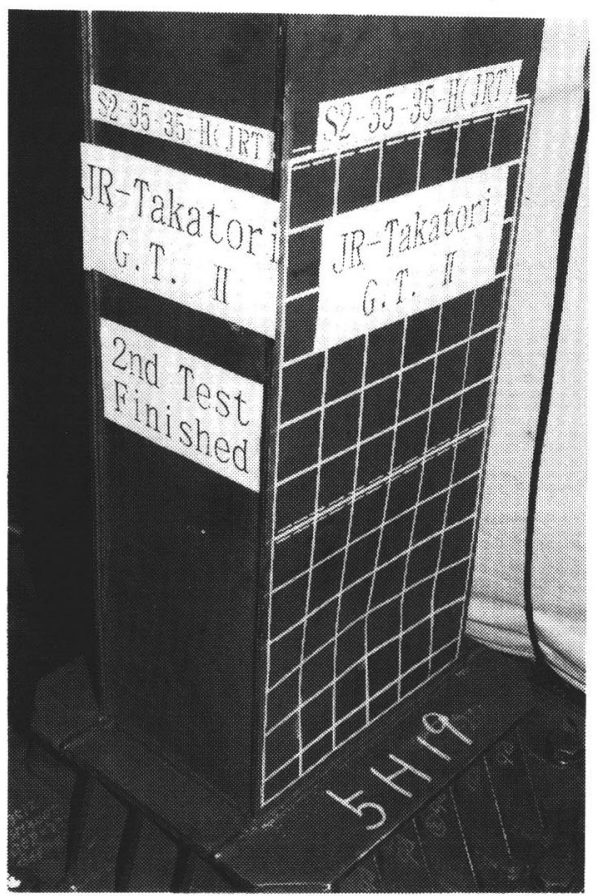

(a) Specimen No.6 $[\alpha=1.0]$

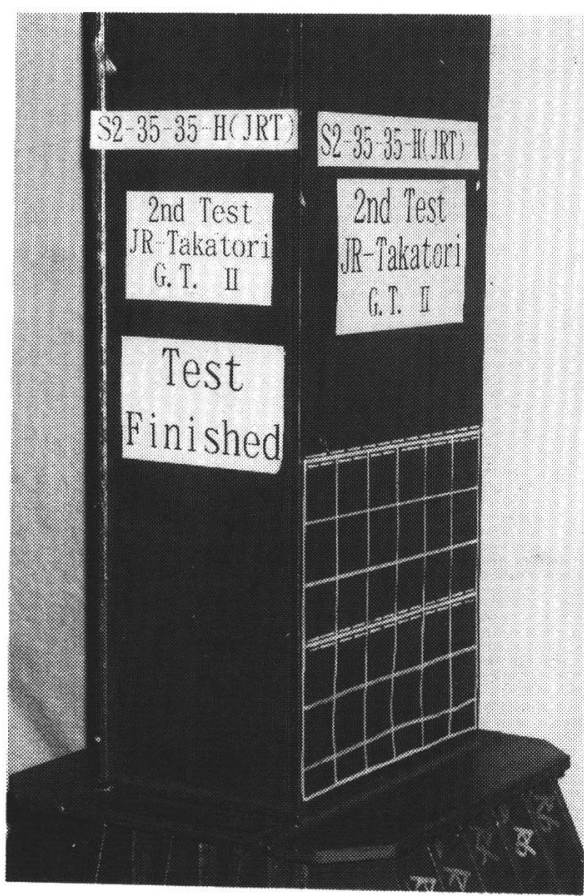

(b) Specimen No.3 $[\alpha=0.5]$

Photo 1 Damaged Test Specimens (JR-Takatori)

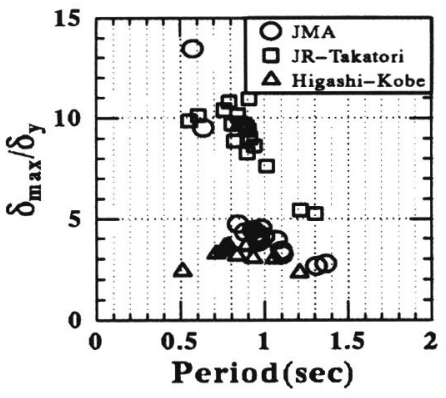

(a)Maximum Displacement

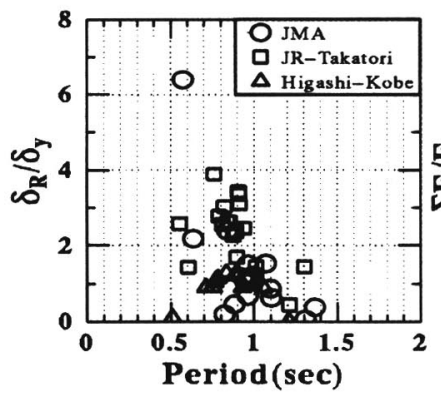

(b)Residual Displacement

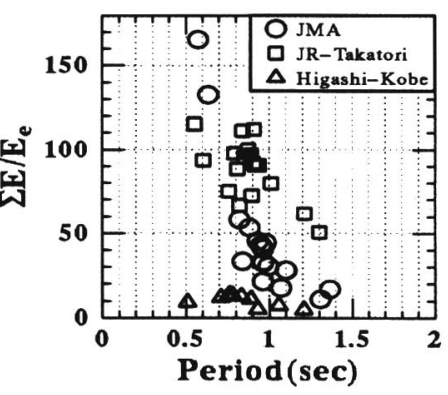

(c) Cumulative Absorbed Energy

Fig.9 Maximum Displacement, Residual Displacement and Cumulative Absorbed Energy Spectra 
は，次節で再度述べる。

\section{（3）増幅地震波に対するハイブリッド地震応答実医 結果}

Fig.6, Fig.7およびFig.8に増幅地震動入力による八 イブリッド地震応答実験結果を示す，ただし，No.6お 上びNo.7 供試体は増幅前の地震波により，既にある程 度の損傷を受けているため，これらの供試体に対する 考察㹥定性的なものである.

Fig.6(b) の供試体 No.4 は損傷のない状態で(JMA)L 地震動を入力して実験が行われたもので, JMA 地震動 を入力した Fig.3(b)の No.3 と同-.-寸法の供試体であ る. 両者の結果を比較すると, 入力加速度を 1.5 倍に增 幅したことにより，最大応答は $12 \%$ 大きくなっている. しかし残留变位は逆に元の地震波の $57 \%$, 小さくなっ ている.この結果崎妙に感じられるので, 詳しく考 察してみる。これまでのハイブリッド地霞応答実験で は, 最大灾答变位と残留変位は同じ方向に生ずるのが ほとんどであった，すなわち，残留変位は最大応答変位 時に傾いた方向に生ずる場合が圧倒的に多い，今回の 実験でもほとんどそのようなケースであった．例外は， (JMA)L を入力した No.4 供試体のみであり，最大応答 変位が $(+)$ 側, 残留変位が $(-)$ 側である. 一方, JMA 人力したNo.3 供試体はいずれも(-) 側であった.No.3 供試体は，最初の大きな波で $(+)$ 側に $\delta / \delta_{y}=+2.5$ だけ 傾くが，次の波の摇れ戻しで(-)側に大きく变位して最 大念答変位 $(-3.84)$ を迎え，その後はそれまでの変位の 正負の最大值の閒（すなわち，-3.84〜+2.5）で振動を 繰り返し最終的に(-) 側に残留変位が生じている. 一方, No.4供試体は, 加速度が増幅されているため, 最初の 大きな波で $(+)$ 側にNo.3 より大きな変位 $(+4.43)$ が生 じる.これが, この供試体の最大応答变位であり, 次 の波で $(-)$ 側に変位するものの. 最初の $(+)$ 側への变位 が大きかった分，摇れ戻しによる変位はNo.3 と同程度 の $(-3.9)$ に収まっている，その後壮，No.3供試体と同 じように変位振幅 $(-3.9 \sim+4.43)$ の間で振動し, 最終的 に(-)側の変位が残留するが，(+)側の変位が大きかっ た分, No.3 供試体より残留变位が小さい結果になった ものと思われる. 寸なわち，この場合は，(+)側に橋脚 を変位させる地震波の成分によって, 構造物が (-) 側に 傾くのを助ける形になっている. 以上の考察より, 加 速度を増幅しても残留変位忙必ずしも大きくなるわけ ではなく，かえって小さくなる場合もあることが分か る。この事実は, 残留変位の推定の難しさを示してい るが，このような例は非常に特殊な場合で，多くの場 合は, 前述のように最大応答変位と残留変位は同符号 であるので, 最大応答変位が大きくなれば残留変位も 大きくなる．最大応答変位と残留変位の関係について
Fig.6(a), Fig.6(c)のNo.6 №.7 はそれぞれ過去 に 2 種類の増幅前の地震波を入力した後の供試体であ り、前述のようにそれらの供試体の実験結果は処女供 試体の実験結果と異なることが推測される. しかし，こ れらの実験結果を見てみると，双方ともに最大応答時 での耐力の劣化は見られず, 従って, 局部座屈の発生 が肉眼ではほとんど見られない程度の損傷であること が分かる.

Fig.7の JR-Takatori の増幅地震波では, No.5 供試体 で $\delta_{\max } / \delta_{y}=13.7$ と非常に大きな応答を示し, 最大耐 力を過ぎ劣化が生じている. No.6 では地震開始 5.8 秒 で最大応答 $\delta_{\max } / \delta_{y}=9.28$ を生じ, その後耐力が降伏 水平变位 $H_{y}$ まで低下している. それに対し, No.7 は最 大応答 $\delta_{\text {max }} / \delta_{y}=10.6$ に対しても, 耐力の劣化は生ぜ ず，しかも残留変位もかなり小さくなっている.JMA， JR-Takatori，JMA 増幅地震波を入力した後の実験にも かかわらず，損傷の少ない優れた耐震性能を発揮した ことがわかる.

Fig.80 Higashi-Kobe 増幅地震波については最大応 答 $\delta_{\max } / \delta_{y}=5.89$ を生じているが耐力の劣化は見られ ない.

\section{5. 最大応答変位, 残留変位, 累積履歴吸収 エネルギースペクトル}

本研究の実験結果の内，増幅地震波入力の実験を除 いた実験の結果を, 横軸に固有周期を, 綐軸に最大応 答変位, 残留変位および累積吸収エネルギーをとった グラフ(それぞれ最大応答変位スペクトル, 残留変位ス ペクトル, 累積履歴吸收エネルギースペクトルと呼ぶ) をFig.9に示寸，同図中には，過去に名古屋大学で行な われたハイブリッド地震态答実験結果 ${ }^{9}$ の内, ハイダク ティリティーの条件を満足する補剛箱形断面供試体の 実験結果も合わせて示す.

Fig.9(a)の最大応答変位スペクトルを見ると, JMA， JR-Takatoriに対しては最大忍答変位は固有周期の変動 に非常に敏感で，しかも固有周期が小さい領域で非常 に大きな值を示すことが分かる. JMA に関しては, 最 大応答変位は固有周期が $0.5 \sim 0.7$ 秒で非常に大きいが, 固有周期が 0.7 秒以上になると急激に小さくなる. とこ ろが，JR-Takatori は 0.5 1 秒前後まで大きな応答が続 く. 本研究の供試体の固有周期は 0.9 秒前後であったた め，大きな最大忘答を示した. Higashi-Kobeに関して は固有周期の変動にほぼ無関倸に一-定の比較的小さい 最大応答を示す。

Fig.9(b)の残留変位スペクトルに関しても最大态答 変位スペクトルとほぼ同じようなことがいえる．JMA 


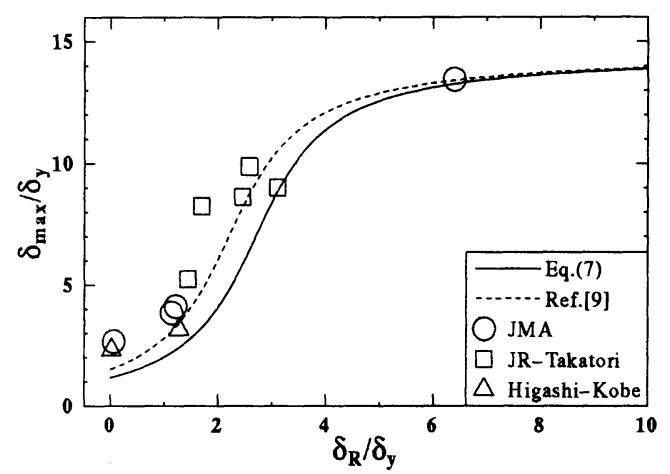

Fig.10 Comparison of Eq.(7) with Test Results

では固有周期が小さくなるに従い，残留变位が大きく なっているのに対して, JR-Takatori では 0.5 秒 1.0 秒 の範囲で大きな残留変位を生じている. Higashi-Kobe については最大応答変位と同様に固有周期の変動にほほ 無関係に，---定の比較的小さな残留変位を生じている.

また，Fig.9(c)の累積吸収エネルギースペクトルに ついても, 最大态答変位スペクトルと似た傾向を示し ている. Higashi-Kobeは固有周期の変動にほぼ無関倸 で一定値を示すのに対し，JMA は小さな固有周期では 大きな履歷吸収エネルギーを示しているものの, 固有 周期が 1 秒を越えるは急激に值が小さくなる.しかし， JR-Takatori は比較的大きな值が固有周期の 1.2 秒程度 まで続く。

\section{6. 最大応答変位と残留変位の関係}

本研究で行ったハイブリッド地震态答実験結果の内, ハイダクティリティー鋼製橋脚の設計思想に基づいて 設計した供試体の最大忘答変位 $\delta_{\max }$ と残留変位 $\delta_{R}$ の関 係をプロットしたものを Fig.10に示す．ただし，増幅 地震動に対寸る実験結果は除いてある，前述のように， 最大応答変位の方向と残留変位の方向が逆の場合には, それらの間に比例的な関係は見られなかったものの，こ の図から， $\delta_{\text {max }}$ と $\delta_{R}$ はほぼ比例関係にあると見なすこ とが出来よう。これらの結果より, 次式で示す経験式を 求めた。

$$
\frac{\delta_{R}}{\delta_{y}}=\tan \left(0.208 \frac{\delta_{\max }}{\delta_{y}}-1.46\right)+2.7 \geq 0.0
$$

ここで，適用範囲は，

$$
\frac{\delta_{\max }}{\delta_{y}} \leq 14.2
$$

式(7)は文献9)のコンクリート部分充填鋼製橋脚に 対する経験式（図中の点線で表される曲線）の係数の みを変えた (すなわち, 右辺の最終項の数值 2.2 を 2.7 に変えた)ものであるが，提案推定式は，最大态答変位
と残留変位の相関曲線の下界曲線をほぼ示すことが出 来ている．ただしこの推定式は，補剛箱形断面鋼製橋 脚で，かつ，提案するハイダクティリティーの設計思 想に準じた橋脚に対してのみ適用できるものである.

\section{7. 結言}

文献1)で提案されたハイダクティリティー鋼製橋脚 の設計思想は, 板パネルの幅厚比を制限し, 補剛材剛 度を上げることにより局部座屈の発生・進展を遅らせ， さらに細長比を制限することにより部材全体のP- $\Delta$ 効 果を小さくして，鋼部材のみで耐震性能を高めるとい うことであった．この効果を実証するため，兵庫県南部 地震で観測された 3 種類の地震波 (神戸海洋気象台, JR 鷹取駅, 東神戸大橋)およびそれら加速度を一様に 1.5 倍に增幅した地震波を用いたハイブリッド地震応答実 験を実施した。供試体は寸法が同一のものを 7 体準備し た. その内の 1 体 (No.6) は, 縦方向補剛材の剛比が小 さいためハイダクティリティの基準を満たさない供試 体であり，また 1 体 (No.7) はハイダクティリティーの 基準を満たすと共に縦方向補剛材に板バネルより高強 度の鋼材 (板パネル:SS400, 補剛材: SM570)を用いた ハイブリッド補剛断面供試体である。一連の実験によっ て得られた結論をまとめると以下のようになる

（1）提案したハイダクティリティー橋脚は, 最高荷重時 の変位塑性率 $\delta_{m} / \delta_{y}$ が 6.0 程度という高い変形能を 有していることが準静的実験から分かった. この塑 性率は設計時の予測值とほぼ同じ大きさであった。

(2) 兵庫県南部地震での観測地震波およびその増幅地 震波に対するハイダクティリティー橋脚の耐震性 能は非常によく, 最大応答変位 $\delta_{\max }$ が $10 \delta_{y}$ 程度の 大きな変位が生じたときでも, 復元力ー水平変位 関係に少化域が生ぜず，従って供試体には局部座 屈がほとんど見られなかった。

(3) その中でもハイブリッド補剛断面供試体の耐震性 能は特に優れており, 最大忘答変位および残留変 位とも他の供試体より小さくなる.

（4）それに対し，ハイダクティリティーの条件を満足 しない供試体 No.6 は, JR鷹取駅地震波に対して 劣化域が生じ, 局部座屈がかなり大きく生ずるよ うな㐫答を示した。

(5) 文献9) で提案した最大忘答変位と残留変位の相関 式(7) は釈数を変えるだけで、今回の実験に対し ても良い精度で適用できることが分かった。

上記のように，提案設計法は耐震性能のよい鋼製橋 脚の設計法として有力であることが分かったが, 問題 点がないわけではない，それらを列举して今後の研究 課題としたい. 
(1) 橋脚の固有周期によってはハイダクティティー橋脚 といえども応答変位および残留変位は非常に大き くなる.JR鷹取駅地震波に対しては固有周期 0.5 $\sim 1$ 秒前後, 神戸海洋気象台に対しては $0.5 \sim 0.7$ 秒 前後の橋脚である.このような橋脚に対しては, 忘 答変位特に残留変位を抑制する方策を考える必要 がある. 例えば3)，(1)コンクリートを橋脚基部に部 分的に充填する, (2)震度法による1 次設計時に安 全率を上げる，またはこれと同じことであるが作 用軸力を下げる, (3)免震構造を導入し, 最大応答 変位を抑制する，などが考えられる。

(2) 提案設計法では, 式(1)の条件のもとで, 目標塑性 率を 6.0 程度とするために, 細長比に制限を設けて いる. (式(4)). これら制限を設けた設計により, 準 静的実験結果では, $P-\Delta$ 効果が抑制され, 優れ た強度と変形能が示された。しかし, 橋脚の細長 比が大きくなれば, 固有周期が長くなるため, 最 大㐫答変位および残留変位は, 細長比が小さいも のに比べ，かえって小さくなる(Fig.9および文献 10)). 寸なわち, 目標塑性率 (要求性能) は小さく て済もわけである. 今後は, 地震外力から構造物 に要求される要求性能がどれだけであるかをまず 算定し，それに見合った保有性能を構造物に具備 させると言う観点からの研究を進めていく必要が ある11)。

本研究は, (社) 日本橋梁建設協会から名古屋大学へ の委託研究 (平成 8 年度) として行われた.

\section{考文姑}

1) 宇佐美勉: ハイダクティリティー鋼製橋脚, 橋梁と基礎, Vol.31, No.6, pp.30-36, 1997 年 6 月.

2) 宇佐美勉, 鈴木森晶, Iraji H.P.Mamaghani, 葛 漢涁 : コンクリートを部分的に充填した鋼製橋脚の地震時保有 水平耐力照査法の提案, 土木学会論文集, No.525/I-33, pp.69-82, 1995 年 10 月.

3) 士木学会鋼構造委員会 ·鋼構造新技術小委員会・耐震設 計WG（主查 : 宇佐美 勉）：鋼橋の耐震設計指針案と耐 震設計のための新技術, 1996 年 7 月.

4) 日本道路協会 : 道路橋示方書・V 耐震設計編, 丸善, 1996 年 12 月。

5) 鈴木森晶, 宇佐美勉 : 軸圧縮力と横力を受ける箱形断面 鋼片持柱の強度上変形能に関する解析的研究, 構造工学 論文集, Vol.41A,pp.265-276, 1995 年 3 月.

6) Nakamura, Yutaka : "Waveform and its Analysis of the 1995 Hyogo-Ken-Nanbu Earthquake", JR Earthquake Information, No.23c, Feb., 1995, Railway Technical Research Institute.

7）才塚邦沄, 伊藤義人, 木曽英滋, 宇佐美勉 : ハイブリ ッド地震応答実験手法に関する考察, 土木学会論文集, No.507/I-30, pp.179-190, 1995 年 1 月.

8) Shen, C., Mizuno, E. and Usami, T.: Cyclic Behavior of Structural Steels. II: Theory, J. of Eng. Mech., ASCE, Vol.121, No.11, pp1165-1172, 1995.

9）才塚邦宏, 宇佐美勉, 芳崎一也, 鈴木森晶 : 兵庫県南部 地震観測地震波を用いたハイブリッド地震忘答実験によ る鋼製橋脚の激震挙動, 土木学会論文集, No.556/I-38, pp.119-129, 1997 年 1 月

10) 鈴木俊光, 宇佐美勉, 伊藤義人, 豊島径 : 細長比の大き なコンクリート部分充填柱の強震時挙動, 土木学会論文 集, No.537/I-35, pp.77-88, 1996年 4 月.

11) 宇佐美勉, 水越秀和, 鈴木森晶 : 鋼製橋脚の要求性能上 保有性能, 橋梁と基礎, Vol.32, No.1, pp.45-49, 1998 年 1 月.

(1997. 4.8 受付)

\title{
EXPERINENTAL STUDY ON THE SEISMIC PERFORMANCE OF HIGH DUCTILITY STEEL BRIDGE PIERS
}

\author{
Tsutomu USAMI, Koichi WATANABE, Tomoaki KINDAICHI, Takashi OKAMOTO and Shigeru IKEDA
}

\begin{abstract}
Seismic behavior of steel bridge piers is influenced mainly by the width-thickness ratio parameter of the flange plate and slenderness ratio parameter of both the column and stiffeners. In this study, a proposal based on the findings from available experimental results is made for designing steel bridge piers with high ductility, and its validity is verified by pseudodynanic tests. A key point of the proposed design method is to increase the deformation capacity by setting upper bounds to both the plate width-thickness ratio parameter and column slenderness ratio parameter, and a lower bound to the relative flexural regidity of the stiffeners. Steel bridge pier models designed in acordance with the proposal were tested using the earthquake accelerograms recorded during the Hyogo-ken Nanbu earthquake. The results have shown that steel bridge pier specimens tested are of very high ductility capacity.
\end{abstract}

